\title{
Effect of long-term administration of metanil yellow on the structure of cerebellar cortex of adult male albino rat and the possible protective role of anise oil: A histological and immunohistochemical study
} Original Article

\author{
Walaa M. Elwan
}

Department of Histology, Faculty of Medicine, Tanta University, Tanta, Egypt

\begin{abstract}
Introduction: Metanil yellow is used as a colorant in many food processing industries. It has toxic effects on some organs in humans and animals. Anise oil, an essential oil of the flowering plant Pimpinella anisum L., possesses a wide range of pharmacological activities and a proposed role in combating some neurological disorders.

Aim: To study the effect of long term administration of metanil yellow on the structure of cerebellar cortex of adult male Albino rats and to evaluate the possible protective role of anise oil.

Materials and Methods: Forty-five adult male albino rats were divided into four groups; Group I (control), group II further divided into two subgroups ( $\mathrm{a}$ and $\mathrm{b}$ ) that received anise oil $(0.5 \mathrm{ml} / \mathrm{kg}$ ) orally for four and eight weeks, respectively., Group III also divided into two subgroups (a and b) orally administered metanil yellow $(200 \mathrm{mg} / \mathrm{kg}$ ) for four and eight weeks, respectively. Alike, group IV divided into subgroups ( $\mathrm{a}$ and $\mathrm{b}$ ) received both anise oil and metanil yellow at the same dose, route and duration as in groups II and III, respectively. Specimens from the cerebellar cortex were processed for light microscopy. Immunohistochemical study was carried out using antibodies against active caspase-3 and glial fibrillary acidic protein (GFAP).

Results: Specimens from metanil yellow-treated animals showed a high significant decrease in the mean number of Purkinje cells, which appeared shrunken, distorted and surrounded by large vacuolar spaces. Some of their nuclei were shrunken and deeply stained, while others were fragmented. The molecular and granular layers displayed prominent perineuronal spaces. Immunohistochemically, highly significant increases in active caspase-3 and GFAP immunoreactions were observed. In contrast, minimal changes were observed in rats treated concomitantly with metanil yellow and anise oil.

Conclusion: Metanil yellow-induced structural changes in cerebellar cortex of adult rat that could be ameliorated by concomitant treatment with anise oil.
\end{abstract}

Received: 05 July 2017, Accepted: 11 January 2018

Key Words: Active caspase-3, anise oil, cerebellar cortex, GFAP, metanil yellow.

Corresponding Author: Walaa M. Elwan, M.D., Department of Histology, Faculty of Medicine, Tanta University, Tanta, Egypt, Tel.: 0020-10 0357 3258, E-mail: w.elwan@yahoo.com.

ISSN: 1110-0559, Vol. 41, No.1

\section{INTRODUCTION}

Synthetic food colors, also called colorants are substances added to food to enhance the aesthetic appeal of food making the food more attractive, and thus increasing the appetite ${ }^{[1,2]}$. The maximum limit of permitted colors to be added in any food should be $100 \mathrm{mg} \mathrm{kg}-1$ or litre- 1 of food; however, excessive amounts of food colors are used in most of cases to give the intended attractive color of the processed food ${ }^{[3]}$.

In Egypt and other developing countries, the uncontrolled use of synthetic food coloring agents has been sharply increased particularly in food used for children nutrition $^{[4]}$. Therefore, more attention must be focused on the pathological effects of color additives.
Metanil yellow is a water soluble monoazo acid dye, with chemical formula $\mathrm{C} 18 \mathrm{H} 14 \mathrm{~N} 3 \mathrm{O} 3 \mathrm{SNa}$. It has wide applications in textiles, cosmetics, plastic laboratories paper printing, leather colour photography and pharmaceutical purposes ${ }^{[5,6]}$. Although its use as a colorant is not permitted, it is still used in many food processing industries as a colorant in ice-creams, soft drinks, sweet meat and beverages ${ }^{[7]}$.

Metanil yellow has been documented to be a potent toxic chemical due to its many toxic effects on some organ systems in humans as well as animals ${ }^{[8]}$. In humans, oral administration of metanil yellow induced toxic methaemoglobinaemia ${ }^{[9]}$. Moreover, colour photography and pharmaceutical purposes ${ }^{[5,6]}$. Although its use as a colorant is not permitted, it is still used in many food processing industries as a colorant in ice-creams, soft drinks, sweet meat and beverages ${ }^{[7]}$. 
Metanil yellow has been documented to be a potent toxic chemical due to its many toxic effects on some organ systems in humans as well as animals ${ }^{[8]}$. In humans, oral administration of metanil yellow induced toxic methaemoglobinaemia ${ }^{[9]}$. Moreover, allergic dermatitis results from its direct contact with the $\operatorname{skin}^{[10]}$. A tumor promotion by metanil yellow has been also documented by some authors ${ }^{[1]}$.

Laboratory data revealed that the administration of metanil yellow in the laboratory animals causes many organ toxicities such as testicular lesions ${ }^{[12]}$ alteration of haematopoietic system and lesions in the stomach, intestine, liver and kidney ${ }^{[13]}$. In addition, chronic consumption of metanil yellow and other synthetic food colorants caused brain toxicity resulting in imbalance in neurotransmitters ${ }^{[14,15]}$.

Anise oil is an essential oil of Pimpinella anisum L., a flowering plant belonging to the Apiaceae family ${ }^{[16]}$. It has been reported to possess a wide range of pharmacological activities such as antioxidant and anti-inflammatory ${ }^{[17]}$, antibacterial and antiviral ${ }^{[18]}$, antifungal ${ }^{[19]}$, antidiabetic ${ }^{[20]}$, in addition to anticancer effects ${ }^{[21]}$. Moreover, it has been used to promote lactation in nursing mothers ${ }^{[22}$, and it can also stimulate immunity ${ }^{[23]}$. However, few studies have investigated the effect of this essential oil on neurological disorders $^{[24]}$.

Based on the aforementioned data, this study aimed to investigate the effect of long term administration of metanil yellow on the histological structure of the cerebellar cortex of adult albino rat, using different histological and immunohistochemical techniques.

\section{MATERIALS AND METHODS}

The present study was carried out on 45 adult male albino rats weighing 180-200 grams each. All animals were housed under standard laboratory conditions with free access to food and water throughout the study period. They were acclimatized to the experimental environment at least 2 weeks before starting the study. The experimental procedures were approved by the local Institutional Animal Ethical Committee of Faculty of Medicine, Tanta University, Egypt.

The animals were divided into four groups: Group I (Control): It included 15 rats subdivided into two subgroups; subgroup Ia (5 rats) that received no treatment, and subgroup $\mathrm{Ib}$ (10 rats) that was further subdivided into two equal subgroups ( $\mathrm{Ib} 1$ and 2) and administered 0.5 $\mathrm{ml} / 100$ gm body weight of distilled water orally once daily for 4 and 8 weeks, respectively.

Group II (Anise oil -treated): 10 rats subdivided into two equal subgroups IIa and $b$ that were given $0.5 \mathrm{ml} / \mathrm{kg}$ body weight of anise oil orally via a gastric tube once daily for 4 and 8 weeks, respectively according to Abdul-Hamid and Gallaly (25). Anise oil was purchased from MOBACO Company, Cairo, Egypt.
Group III (Metanil yellow-treated): It included 10 rats subdivided into two equal subgroups IIIa and $b$ that received metanil yellow $(200 \mathrm{mg} / \mathrm{kg})$ dissolved in distilled water orally via a gastric tube once daily for 4 and 8 weeks, respectively according to that reported by Al-Malki and Al-Sayed ${ }^{[26]}$. The concentration of metanil yellow was prepared in such a way that each rat received $0.5 \mathrm{ml}$ of metanil yellow/100 gm body weight. The chosen dose was lower than $1 / 20$ of LD50 $0^{[27]}$. Metanil yellow was purchased from Sigma Chemicals (Sigma, St Louis, MO) (cat\# 202029) in the form of 100 gm powder in a glass bottle.

Group IV (Anise oil and metanil yellow-treated): It included 10 rats subdivided into two equal subgroups Iva and $\mathrm{b}$ that were concomitantly given both anise oil and metanil yellow at the same doses, routes and duration as in groups II and III, respectively.

At the end of the experiment, all rats were anesthetized by an intraperitoneal injection of pentobarbital $(50 \mathrm{mg} / \mathrm{kg} \text { body weight })^{[28]}$. The scalp had been reflected, then, the sagittal suture was traced with dissecting blade to obtain the cerebellum to be processed for histological and immunohistochemical study.

For light microscopy; specimens were immersed in $10 \%$ neutral-buffered formalin, washed, dehydrated, cleared and embedded in paraffin. Sections of $5 \mu \mathrm{m}$ thickness were stained with haematoxylin and eosin (H\&E $)^{[29]}$.

For immunohistochemistry; $5 \mu \mathrm{m}$ thick sections were dewaxed, rehydrated, and washed with phosphate buffered saline (PBS). The sections were then washed in PBS and incubated for $10 \mathrm{~min}$ at room temperature with $10 \%$ goat serum to block unspecific binding. The sections were then incubated overnight in a humid chamber with the primary antibody at $4{ }^{\circ} \mathrm{C}$ (rabbit polyclonal anti-rat activated caspase-3 antibody (ab2302; Abcam, Cambridge, Massachusetts, USA), rabbit polyclonal anti-rat glial fibrillary acidic protein (GFAP) (ab116010). Washing in PBS buffer and co-incubation with biotinylated secondary antibody for one hour at room temperature was carried out. Streptavidin peroxidase was then added for 10 minutes and rinsed again three times in PBS. Immunoreactivity was visualized using 3, 3'diaminobenzidine (DAB)-hydrogen peroxide as a chromogen. Sections were counterstained with Mayer's haematoxylin. The negative control sections were prepared by excluding the primary antibodies (30). Positive controls for active caspase- 3 were camptothecintreated Jurkat cells. Positive controls for GFAP were human brain or astrocytoma tissues. Active caspase-3immunostained cerebellar sections were considered positive upon expressing clear evident brown nuclear and/or cytoplasmic coloration. GFAP-immunostained cerebellar sections were considered positive upon expressing clear evident brown cytoplasmic coloration.

\section{Morphometric study}

The images were obtained using a Leica microscope (DM3000, Leica, Germany) coupled to a CCD-camera 
(DFC-290, leica, Germany). The image analysis was done using Leica Qwin 500 C image analyzer computer system (Leica Imaging System LTD., Cambridge, England) at the Central Research Lab, Faculty of Medicine, Tanta University, Egypt.

-Ten different non-overlapping randomly-selected fields from each slide were quantified for:

1- The mean number of Purkinje cells per millimeter length of the cerebellar lobules (at $\times 200$ magnification).

2- The mean number of active caspase-3 positive cells was counted in an area of $20 \mathrm{~mm} 2$ (at $\times 400$ magnification).

3- The mean percentage (\%) of GFAP positive cells (in DAB-stained sections) in relation to the total number of cells (at $\times 400$ magnification).

\section{Statistical analysis}

Data were analyzed by using one-way analysis of variance (ANOVA) followed by Tukey's test for comparison between the groups using statistical package for social sciences statistical analysis software (version 11.5; SPSS Inc., Chicago, Illinois, USA). All values were expressed as mean \pm standard deviation. Differences were regarded as significant if probability value $p<0.05$ and highly significant if $p<0.001^{[31]}$.

\section{RESULTS}

No deaths were observed during this study.

\section{Histological results:}

Group I (control): Control rats showed the cerebellar cortex formed of three layers; molecular layer, Purkinje cell layer and granular cell layer (Fig. 1). The molecular layer contained numerous nerve fibers together with few superficial small stellate cells and deep basket cells. The Purkinje cell layer was the layer bordering the molecular and granular cell layers, and it consisted of flask shaped cells having rounded vesicular nuclei with prominent nucleoli. The granular cell layer was composed of closely packed small rounded cells with deeply stained nuclei together with non-cellular areas (cerebellar islands or glomerulus) representing the synapses between the axons entering the cerebellum from outside and the dendrites of granular cells (Fig. 2)

Group II (anise oil-treated): It showed the same histological structure as the control group.

Subgroup IIIa (metanil yellow-treated for 4 weeks): Examination of H\&E-stained sections showed disorganized Purkinje cell layer and displacement of Purkinje cells downwards in the granular layer and upwards in the molecular layer (Fig. 3). In addition, an apparent reduction in the number of Purkinje cells was noticed and the few seen Purkinje cells appeared irregular and shrunken with darkly stained nuclei and darkly stained cytoplasm, while others had ill-defined nuclei and eosinophilic homogenization of the cytoplasm. The affected Purkinje cells were surrounded by unstained pericellular haloes (Fig. 4).

Subgroup IIIb (metanil yellow-treated for 8 weeks): A marked neuronal affection was observed, and most of the Purkinje cells were lost. The few Purkinje cells appeared distorted with irregular outlines, some of their nuclei were shrunken and deeply stained, and others were fragmented, or had peripheral chromatin margination.

The affected Purkinje cells were surrounded by prominent large vacuolar spaces and numerous neuroglia. In addition, the molecular layer and granular layers displayed large prominent perineuronal spaces, and the cells in the granular layer appeared with shrunken deeply stained nuclei. (Figs. 5- 7)

Subgroup IVa (anise oil and metanil yellow-treated for 4 weeks): H\&E stained sections of this subgroup revealed results almost similar to that of the control group. Nevertheless, few Purkinje cells appeared shrunken and darkly stained (Fig. 8).

Subgroup IVb (anise oil and metanil yellow-treated for 8 weeks): H\&E stained sections of this subgroup revealed that Few Purkinje cells were still affected in between many more or less normal cells. Some of them were shrunken, darkly stained, and surrounded by unstained haloes. Moreover, few empty spaces were observed in the molecular and granular layers (Fig. 9).

\section{Immunohistochemical results}

\section{Active caspase-3 immunostaining:}

In the control group, sections immunostained with active caspase- 3 showed a faint positive reaction in few cells in the 3 cortical layers (Fig. 10). In subgroup IIIa, a strong positive cytoplasmic immunoreaction was detected in many cells in the 3 cortical layers (Fig. 11). In subgroup IIIb, the active caspase- 3 positive cells were more numerous in the three cortical layers (Fig. 12). Subgroup Iva revealed weak positive cytoplasmic immunoreaction in few cells within the Purkinje cell layer (Fig. 13). In subgroup IV b, some cells in the Purkinje cell layer exhibited a moderate positive cytoplasmic immunoreaction (Fig. 14).

\section{GFAP immunostaining:}

In the control group, sections immunostained with GFAP showed few astrocytes in the granular and occasionally the molecular layers exhibiting a weak positive cytoplasmic immunoreaction (Fig. 15). In subgroup IIIa, many astrocytes in the three cortical layers showed a strong positive cytoplasmic immunoreaction(Fig. 16). In subgroup $\mathrm{IIIb}$, the GFAP positive cells were more numerous in the three cortical layers (Fig. 17). In subgroup IVa, a moderate positive cytoplasmic immunoreaction was detected only in few astrocytes in the granular and the molecular layers (Fig. 18). While, in subgroup IV b, some astrocytes in the granular and the molecular layers exhibited a moderate positive cytoplasmic immunoreaction (Fig. 19). 


\section{Morphometric and statistical analysis (Table 1, Histogram 1):}

The mean number of Purkinje cells was highly significantly decreased in subgroups IIIa and b compared to groups I and II. In subgroups IVa and $b$, it was highly significantly increased compared to subgroups IIIa and b, respectively but, it still showed a high significant difference compared to groups I and II.

The mean number of active caspase-3 immunohistochemical positive cells was highly significantly increased in subgroups IIIa and b compared to groups I andII. In subgroups IVa and b, it was highly significantly increased compared to subgroups IIIa and b, respectively but, it still showed a high significant difference compared to groups I and II.

The mean percentage (\%) of GFAP immunohistochemical positive cells was highly significantly increased in subgroup IIIa and b compared to groups I and II. In subgroups IVa and b, it was highly significantly increased compared to subgroups IIIa and b, respectively but, it still showed a high significant difference compared to groups I and II.

Table 1: Morphometeric analysis of the cerebellar cortex specimens of all groups

\begin{tabular}{lcccccc}
\hline Parameters & Group I & Group II & Subgroup IIIa & Subgroup IIIb & Subgroup IVa & Subgroup IVb \\
\hline Mean number of Purkinje cells/mm & $25.81 \pm 1.83$ & $25.45 \pm 2.98$ & $7.43 \pm 0.16 \mathrm{a}, \mathrm{b}$ & $5.21 \pm 0.73 \mathrm{a}, \mathrm{b}$ & $19.83 \pm 1.27 \mathrm{a}, \mathrm{b}, \mathrm{c}$ & $15.75 \pm 1.65 \mathrm{a}, \mathrm{b}, \mathrm{d}$ \\
& & & & & & \\
$\begin{array}{l}\text { Mean number of active caspase-3 } \\
\text { cells/20mm2 }\end{array}$ & $0.41 \pm 0.02$ & $0.32 \pm 0.01$ & $20.31 \pm 2.56 \mathrm{a}, \mathrm{b}$ & $26.59 \pm 2.71 \mathrm{a}, \mathrm{b}$ & $9.14 \pm 1.05 \mathrm{a}, \mathrm{b}, \mathrm{c}$ & $11.99 \pm 1.78 \mathrm{a}, \mathrm{b}, \mathrm{d}$ \\
& & & & & & \\
Mean percentage (\%) of GFAP & $8.42 \pm 1.24$ & $8.31 \pm 1.17$ & $34.62 \pm 1.82 \mathrm{a}, \mathrm{b}$ & $38.82 \pm 1.27 \mathrm{a}, \mathrm{b}$ & $\begin{array}{l}12.36 \pm 1.12 \\
\mathrm{a}, \mathrm{b}, \mathrm{c}\end{array}$ & $15.08 \pm 1.17 \mathrm{a}, \mathrm{b}, \mathrm{d}$ \\
\hline
\end{tabular}

Data are expressed as mean \pm standard deviation, a: $p<0.001$ is highly significant versus group $\mathrm{I}, \mathrm{b}: p<0.001$ is highly significant versus group II, c: $p<0.001$ is highly significant versus subgroup IIIa, $\mathrm{d}: p<0.001$ is highly significant versus subgroup IIIb

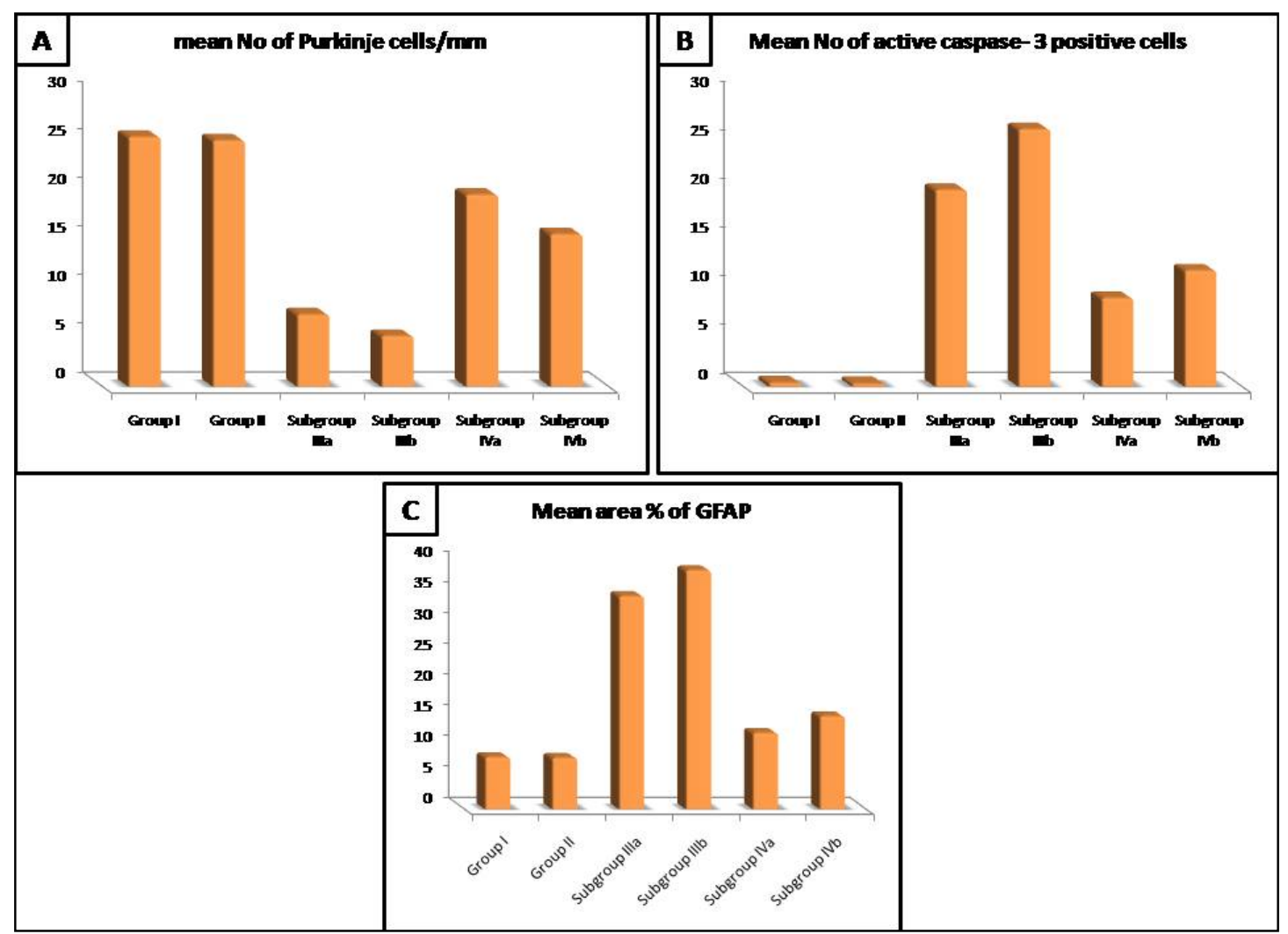

Histogram 1: Morphometeric analysis on biometric values of the cerebellar cortex specimens of all groups. (A) Mean number of Purkinje cells $/ \mathrm{mm}$ length of cerebellar lobules. (B) Mean number of active caspase-3 positive cells $/ 20 \mathrm{~mm} 2$. (C) The mean percentage of GFAP. 


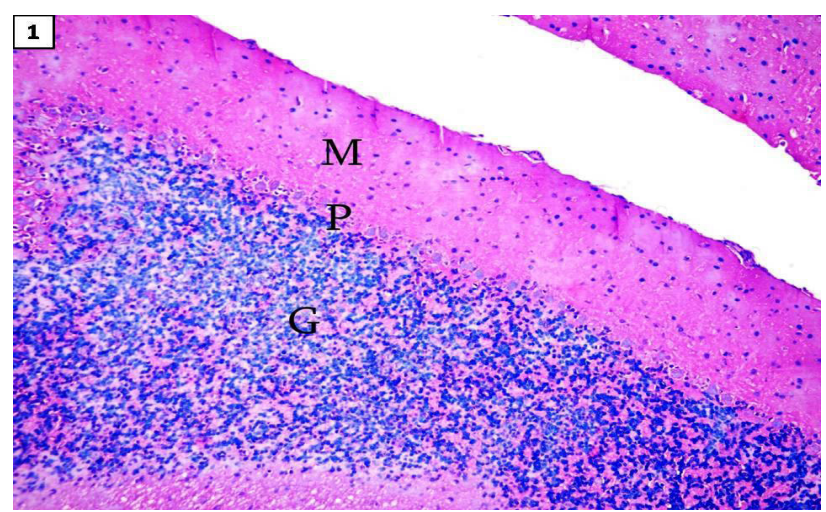

Fig. 1: A photomicrograph of a section in cerebellar cortex of control group I showing the cerebellar cortex composed of three layers; molecular (M), Purkinje (P) and granular (G) layers

$(\mathrm{H} \& \mathrm{E} \times 200)$

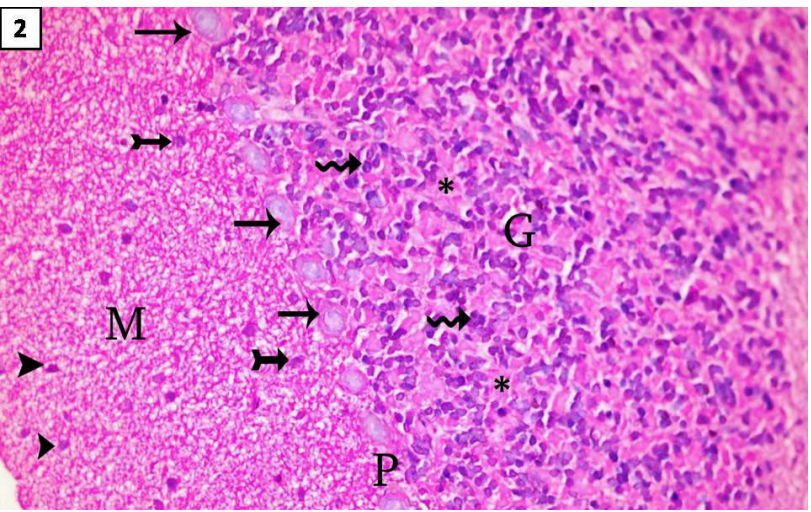

Fig. 2: A photomicrograph of a section in cerebellar cortex of control group I showing the molecular (M) containing numerous nerve fibers together with few superficial small stellate cells (arrow heads) and deep basket cells (notched arrows). The Purkinje layer $(\mathrm{P})$ consists of flask shaped cells (arrows) having rounded vesicular nuclei with prominent nucleoli. The granular (G) layer is composed of closely packed small rounded cells with deeply stained nuclei (wavy arrows) together with non-cellular cerebellar islands (asterisks)

$(\mathrm{H} \& \mathrm{E} x 400)$

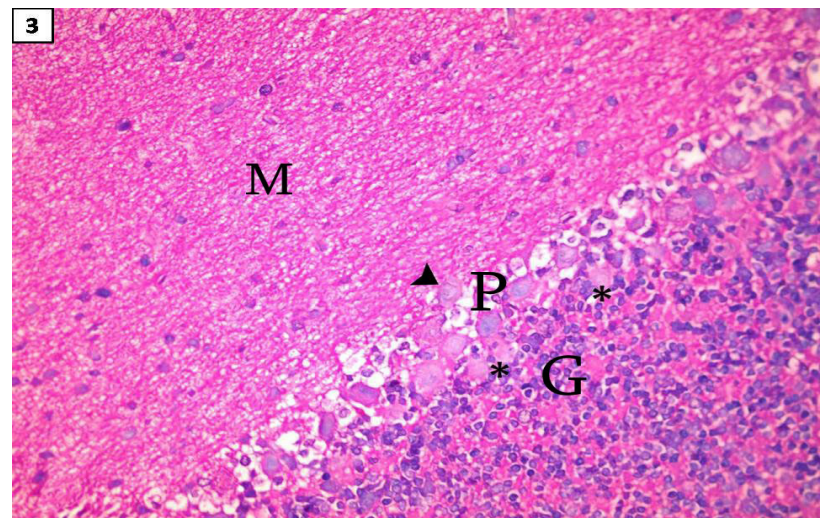

Fig. 3: A photomicrograph of a section in cerebellar cortex of metanil yellow-treated subgroup IIIa showing disorganized Purkinje layer $(\mathrm{P})$ with displacement of Purkinje cells downwards in the granular layer $(\mathrm{G})$ (asterisks) and upwards in the molecular layer (M) (arrowhead)

$(\mathrm{H} \& \mathrm{E} \mathrm{x} 400)$

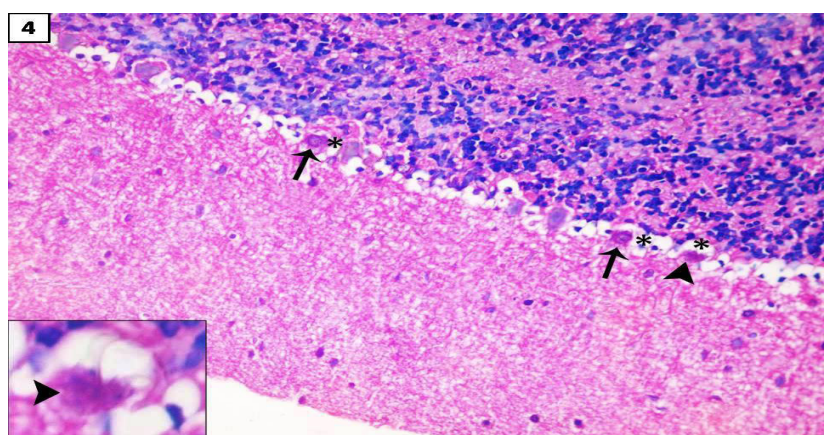

Fig. 4: A photomicrograph of a section in cerebellar cortex of metanil yellow-treated subgroup IIIa showing an apparent reduction in the number of Purkinje cells. Shrunken Purkinje cells with deeply stained nuclei and eosinophilic homogenization of their cytoplasm (arrows) are noticed. Unstained haloes (asterisks) are seen surrounding the Purkinje cells. The inset shows an irregular Purkinje cell with ill-defined nucleus and eosinophilic homogenization of cytoplasm (arrow head).

(H\&E x400, inset x1000)

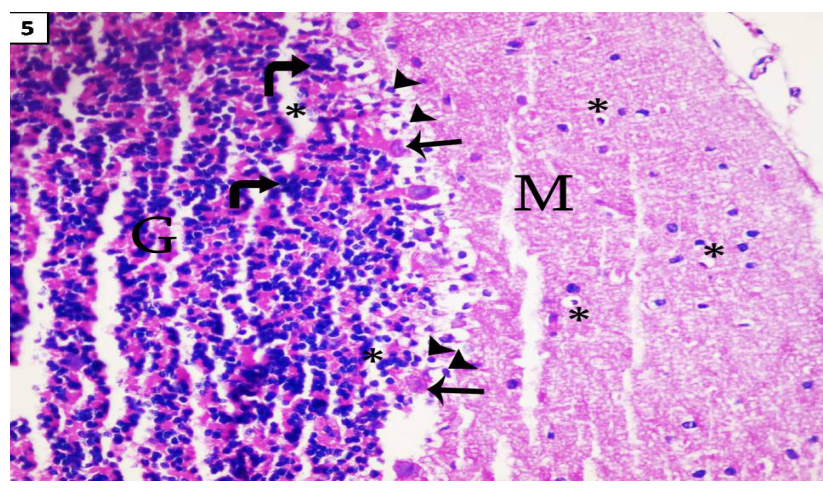

Fig. 5: A photomicrograph of a section in cerebellar cortex of metanil yellow-treated subgroup IIIb showing an apparent marked reduction in the number of Purkinje cells.

Purkinje cells are distorted and shrunken (arrows), and surrounded many nuclei of neuroglia (arrowheads). The molecular (M) and granular (G) layers displayed prominent perineuronal spaces (asterisks). Notice the shrunken deeply stained nuclei of the granule cells in the granular layer (G) (curved arrows)

(H\&E x400)

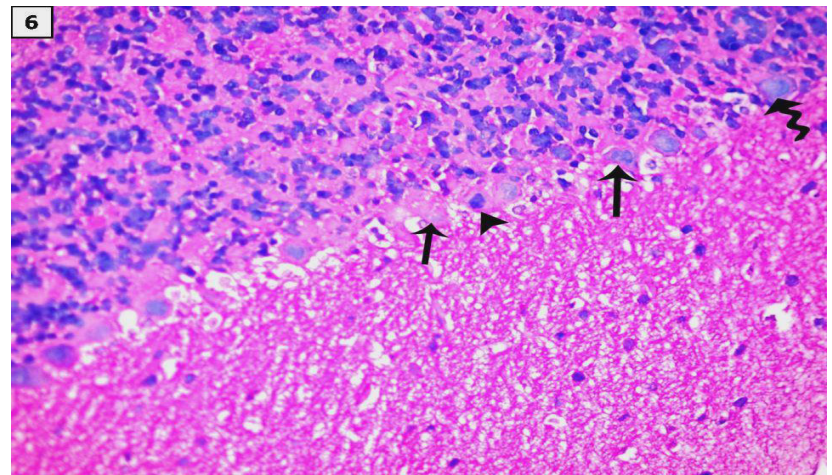

Fig. 6: A photomicrograph of a section in cerebellar cortex of metanil yellow-treated subgroup IIIb showing Purkinje cells with fragmented nuclei (arrows). Another Purkinje cell having shrunken deeply stained nucleus (arrowhead) is seen. Notice a Purkinje cell with peripheral chromatin margination (wavy arrow)

$(\mathrm{H} \& \mathrm{E} x 400)$ 


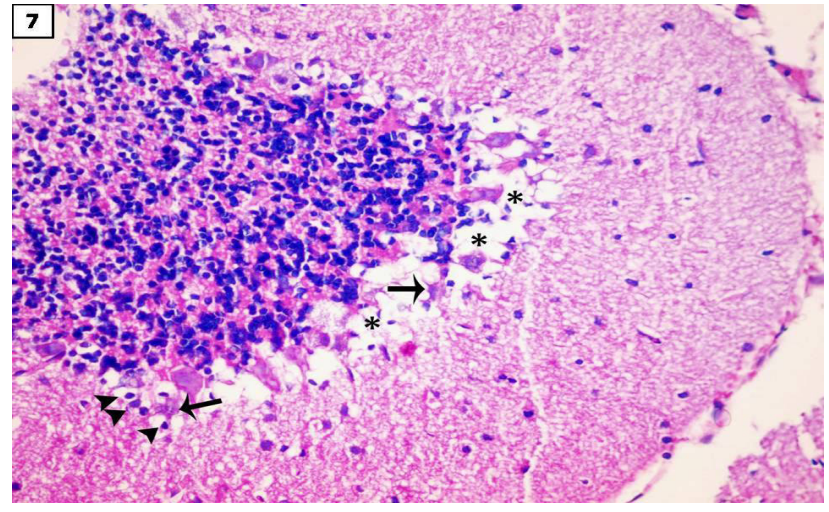

Fig. 7: A photomicrograph of a section in cerebellar cortex of metanil yellow-treated subgroup IIIb showing the Purkinje cells shrunken and distorted with irregular outlines (arrows), and they are surrounded by large prominent vacuolar spaces (asterisks) and many nuclei of neuroglia (arrow heads).

$(\mathrm{H} \& \mathrm{E} \times 400)$

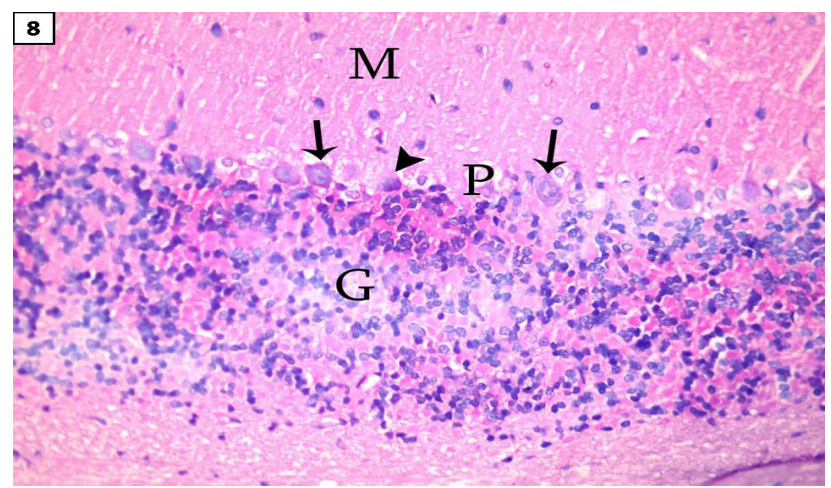

Fig. 8: A photomicrograph of a section in cerebellar cortex of metanil yellow and anise oil-treated subgroup IVa showing apparently normal cortical layers; molecular (M), Purkinje (P) and granular $(\mathrm{G})$ layers. Most of Purkinje cells are more or less normal (arrows). A Purkinje cell (arrow head) is seen shrunken and darkly stained.

$(\mathrm{H} \& \mathrm{E} \times 400)$

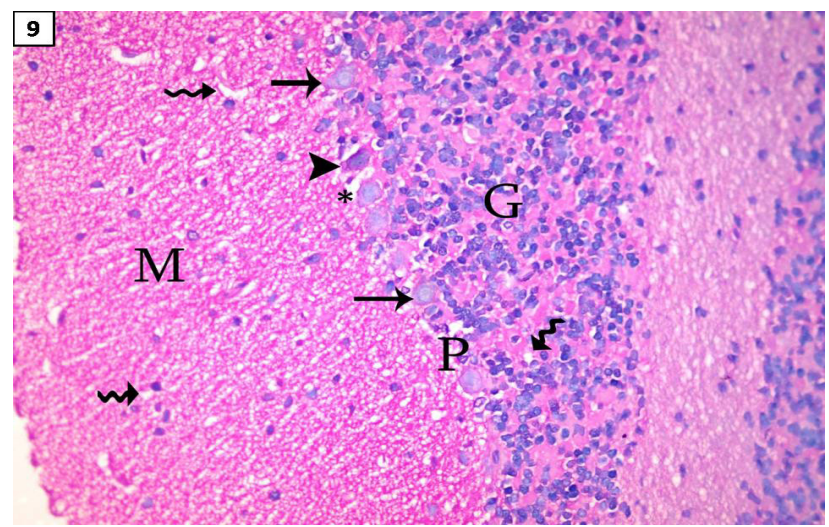

Fig. 9: A photomicrograph of a section in cerebellar cortex of metanil yellow and anise oil-treated subgroup IVb showing most of Purkinje cells are apparently normal (arrows). An irregular Purkinje cell (arrow head) is seen with darkly stained nucleus and cytoplasm and surrounded by unstained haloes (asterisks). Some vacuolar spaces (wavy arrows) in the molecular and granular layers are observed

$(\mathrm{H} \& \mathrm{E} \times 400)$

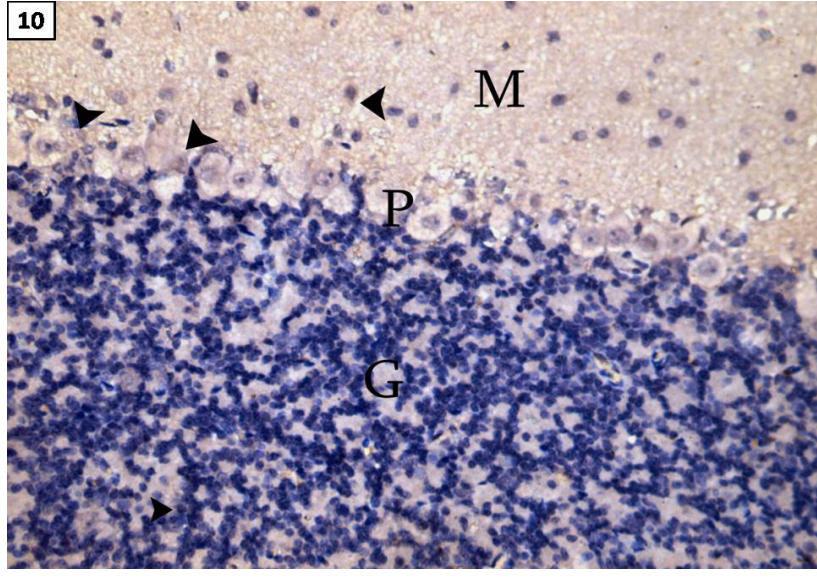

Fig. 10: A photomicrograph of a section in cerebellar cortex of control group I showing a faint positive reaction for active caspase-3 in few cells (arrow heads) in the three cortical layers; molecular (M), Purkinje (P) and granular (G).

(Active caspase-3 x400)

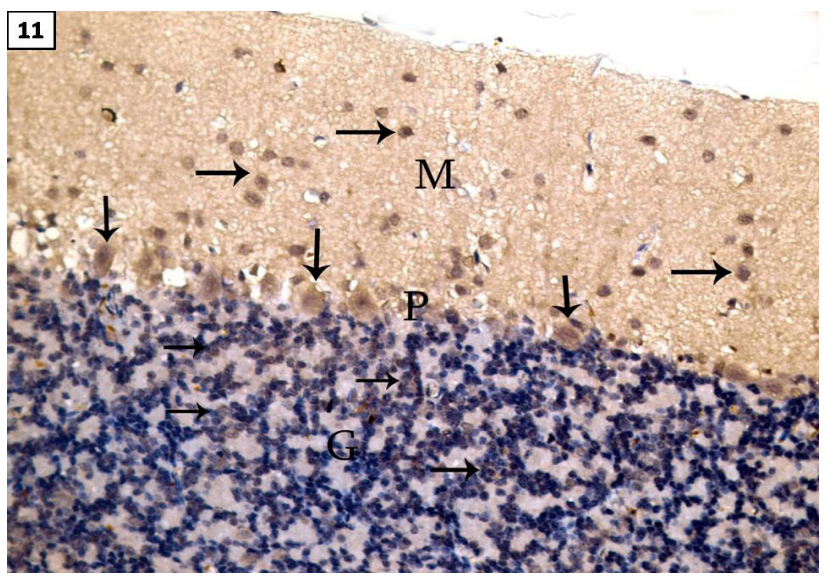

Fig. 11: A photomicrograph of a section in cerebellar cortex of metanil yellow-treated subgroup IIIa showing a strong positive cytoplasmic immunoreaction in many cells in the 3 cortical layers; molecular (M), Purkinje (P) and granular (G) (arrows).

(Active caspase-3 x400)

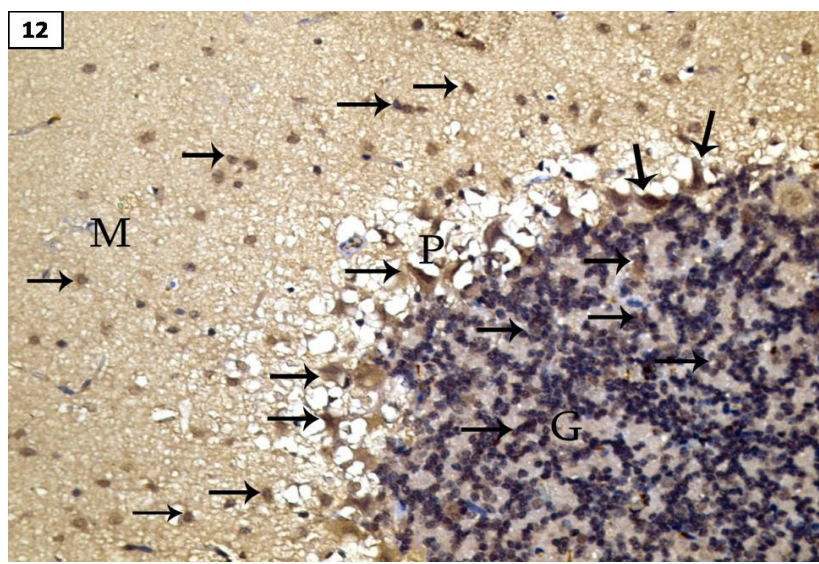

Fig. 12: A photomicrograph of a section in cerebellar cortex of metanil yellow-treated subgroup IIIb showing apparent increase in the active caspase- 3 positive cells in the three cortical layers; molecular (M), Purkinje (P) and granular (G) (arrows).

(Active caspase-3 x400) 


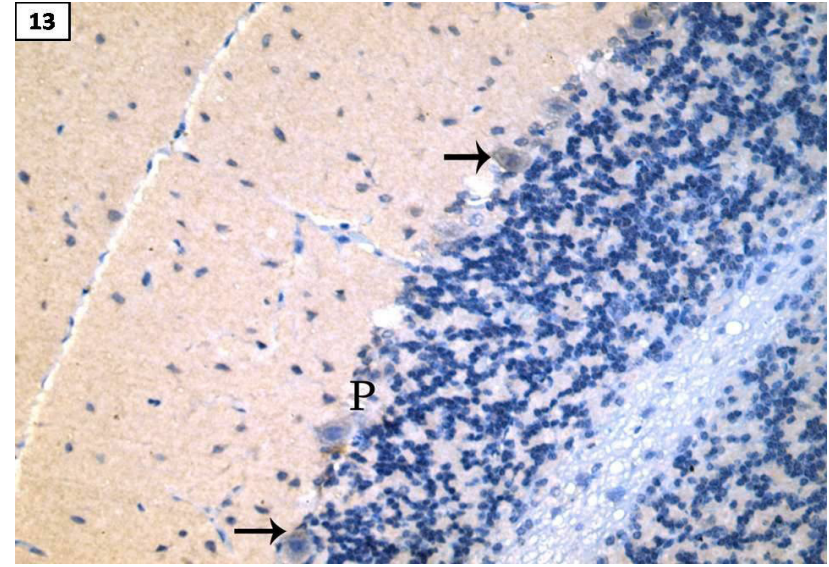

Fig. 13: A photomicrograph of a section in cerebellar cortex of metanil yellow and anise oil-treated subgroup IVa showing a weak positive cytoplasmic immunoreaction in few cells in the Purkinje cell layer (P) (arrows).

(Active caspase-3 x400)

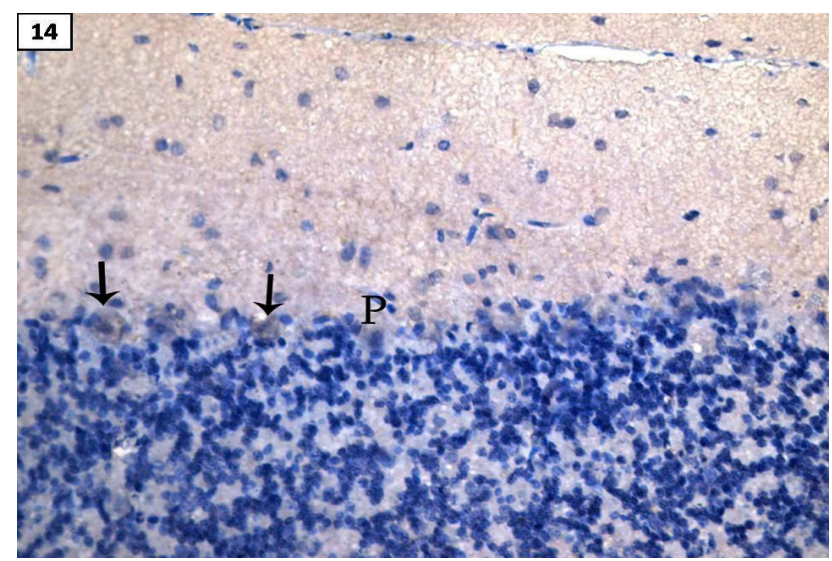

Fig. 14: A photomicrograph of a section in cerebellar cortex of metanil yellow and anise oil-treated subgroup IVb showing a moderate positive cytoplasmic immunoreaction in some cells in the Purkinje cell layer (P) (arrows).

(Active caspase-3 x400)

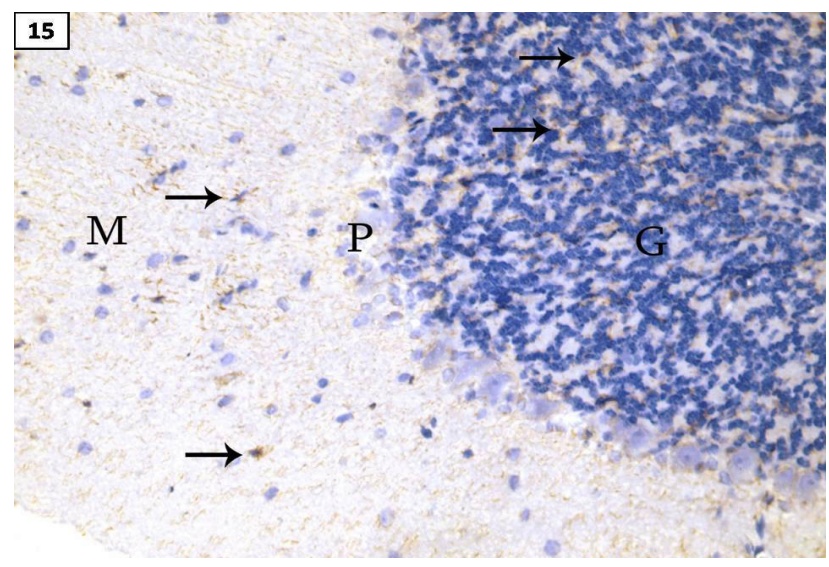

Fig. 15: A photomicrograph of a section in cerebellar cortex of control group I showing few astrocytes in the granular $(\mathrm{G})$ and molecular layers (M) exhibiting a weak positive cytoplasmic immunoreaction (arrows).

(GFAPx400)

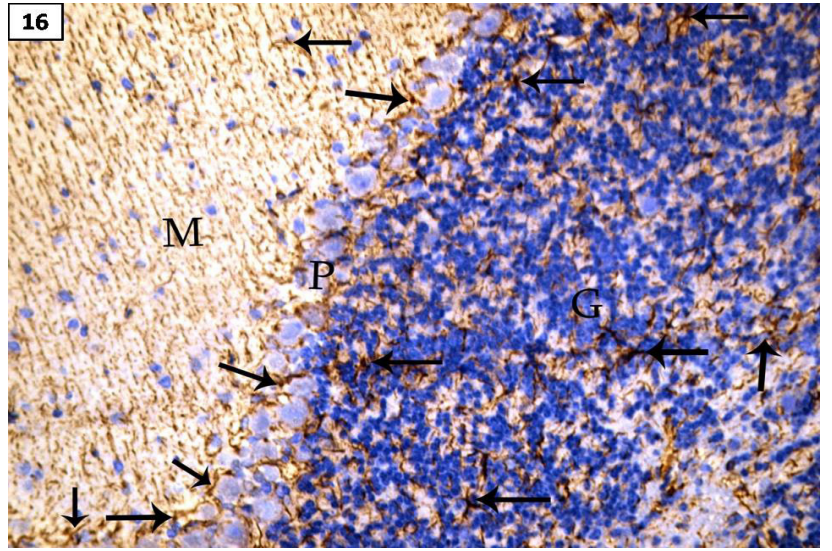

Fig. 16: A photomicrograph of a section in cerebellar cortex of metanil yellow-treated subgroup IIIa showing a strong positive cytoplasmic immunoreactions in many astrocytes in the three cortical layers; molecular (M), Purkinje (P) and granular (G) (arrows).

(GFAPx400)

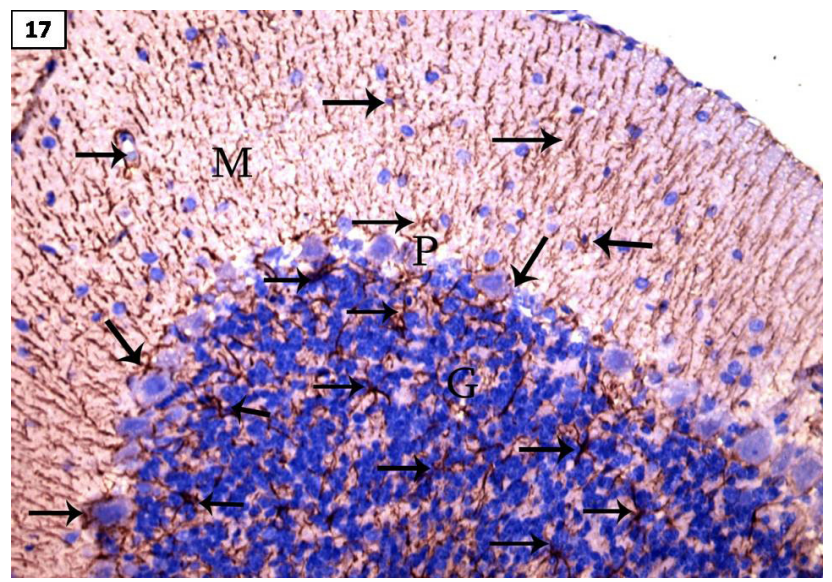

Fig. 17: A photomicrograph of a section in cerebellar cortex of metanil yellow-treated subgroup IIIb showing apparent increase in the GFAP positive cells in the three cortical layers; molecular (M), Purkinje (P) and granular (G) (arrows).

(GFAP x400)

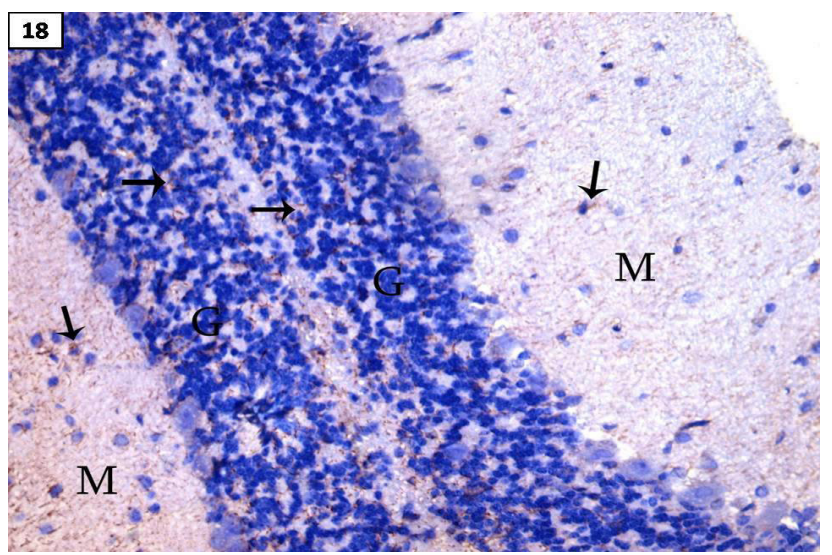

Fig. 18: A photomicrograph of a section in cerebellar cortex of metanil yellow and anise oil-treated subgroup IVa showing a moderate positive cytoplasmic immunoreaction in few astrocytes in the granular $(\mathrm{G})$ and molecular (M) layers (arrows).

$($ GFAP x 400$)$ 


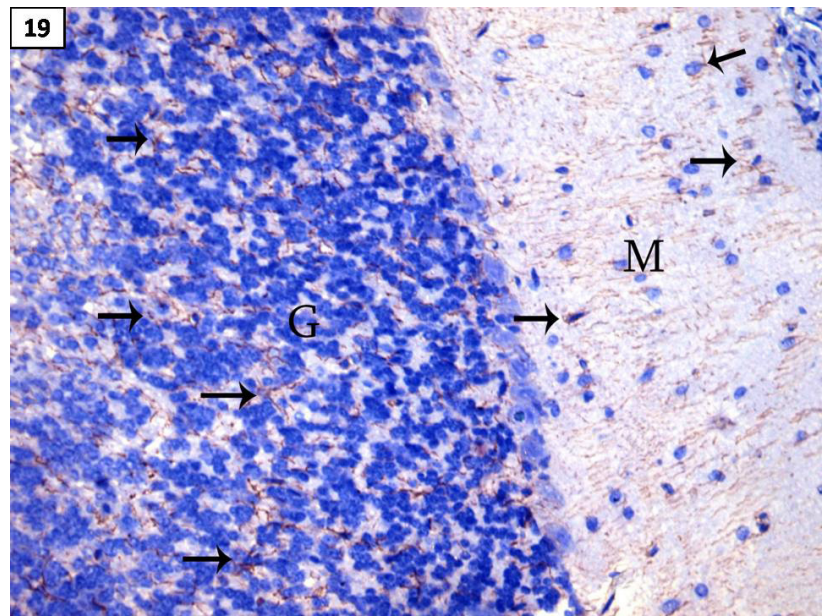

Fig. 19: A photomicrograph of a section in cerebellar cortex of metanil yellow and anise oil-treated subgroup IVb showing a moderate positive cytoplasmic immunoreaction in some astrocytes in the granular $(\mathrm{G})$ and molecular (M) layers (arrows).

(GFAP x400)

\section{DISCUSSION}

Despite the wide spread use of metanil yellow as a synthetic food colorant, there is a growing concern about its many health hazards ${ }^{[32]}$. However, few studies on the effect of metanil yellow on the cerebellum were conducted ${ }^{[33]}$. Anise oil is reported to have protective effects against different cerebrovascular diseases and neurological disorders ${ }^{[24]}$. Accordingly, we aimed to study the effect of long term administration of metanil yellow on the structure cerebellar cortex of adult Albino rat and to evaluate the potential role of anise oil as a protective agent employing different histological and immunohistochemical methods.

In the present study, administration of metanil yellow caused evidence of structural changes in the rat cerebellar cortex mainly in the Purkinje cell layer. These changes reached its maximum at the 8th week of administration resulting in a high significant decrease in the number of Purkinje cells that became damaged and lost. This goes hand to hand with another study that have reported a disorganized Purkinje cell layer and loss of Purkinje cells after metanil yellow administration ${ }^{[33]}$. Moreover, these findings were in accordance with previous studies that reported that chronic administration of metanil yellow predisposed the developing and adult rats to neurotoxicity attributed to alterations of the major neurotransmitter systems ${ }^{[14]}$.

In addition, darkly stained Purkinje cells and granule cells were observed in metanil yellow-treated group that seemsto be resulted from neuronal degeneration ${ }^{[34]}$. Other investigators explained the dark staining of degenerated neurons to be a consequence of an accumulation of denatured proteins resulting from failure of the antioxidant system with subsequent uncompensated oxidative stress $^{[35]}$. On the other hand, these dark neurons were attributed to ischemia, or possibly due to abnormalities in the capillary wall of the cerebellar cortex with subsequent disorders in the structure of blood-brain barrier ${ }^{[36]}$.

In metanil yellow-treated group, the Purkinje cells and granule cells appeared with dark (pyknotic) nuclei. These pyknotic nuclei might be a result of an irreversible condensation of chromatin in cells undergoing programmed cell death or apoptosis ${ }^{[37]}$. In addition, in metanil yellow-treated rats, our results revealed a highly significant increase in the mean number of immunostained cells for active caspase-3, which is an apoptotic marker ${ }^{[38]}$. Thus, we suggest the apoptosis to be a mechanism of metanil yellow induced neurotoxicity. In addition, metanil yellow administration caused nuclear fragmentation of the affected Purkinje cells, and this is one of the apoptotic markers as reported by some authors ${ }^{[39]}$.

In metanil yellow-treated group, the Purkinje cells appeared distorted and shrunken, this might be due to damage in the system responsible for cell proteins biosynthesis. In addition, these shrunken Purkinje cells were surrounded by large prominent pericellular spaces, and this could be attributed to the shrinkage of neurons with subsequent withdrawal of their processes, due to disintegration of their cytoskelelal elements ${ }^{[40]}$.

In fact, the mechanism of metanil yellow induced neurotoxicity is not well known. However, many studies have reported oxidative stress to be the central mechanism of its toxicity, by promoting lipid peroxidation products and reactive oxygen species, and thus, inhibiting endogenous antioxidant defense enzymes and cause brain tissue damage ${ }^{[41,42]}$.

The brain tissue contains relatively low levels of antioxidants and high levels of polyunsaturated lipids, which makes it more vulnerable to oxidative stress compared to other tissues ${ }^{[43]}$. Moreover, the brain tissue displays variations in the cellular and regional distribution of the antioxidant biochemical defenses ${ }^{[44]}$.

In this study, the mean percentage (\%) of GFAP immunostained cells was highly significantly increased as compared with control group. GFAP is an intermediate filament protein known to be specifically expressed in astrocytes, the glial cells that are responsible for repairing and scarring of the brain following injuries ${ }^{[45,46]}$. The increase in GFAP expression has been documented as a biomarker of neurotoxicity ${ }^{[47]}$, wherease exposure to any neurotoxic substances stimulates astrocytes' proliferation and hypertrophy with subsequent increase in the synthesis of GFAP leading to vigorous astrogliosis which is a compensatory neuro-protective process ${ }^{[48,49]}$.

At the protective level, anise oil co-administration with metanil yellow could to some degree preserve the 
structure of the cerebellar cortex at the histological and immunohistochemical levels. This may indicate that anise oil has neuroprotective effect against metanil yellowinduced neurotoxicity. Alike, previous research reported the anise oil as a neuroprotective agent against the cerebellar structural changes induced by chronic administration of other toxic agents such bisphenol $\mathrm{A}^{[50]}$.

In addition, Kahloula and colleagues documented the beneficial effect of anise oil against a variety of neurological disorders such as depression, memory disorders, cerebral ischemia and Alzheimer disease ${ }^{[51]}$. Which might be due to the antioxidant potential of anise oil that protect against various causes of brain damage, and this may be related to its content of the bioactive ingredient; anethole ${ }^{[52]}$ that is structurally related to dopamine and catecholamines. Noteworthy, anethole is a widely used substrate for synthesis of many drugs of neuro-pharmaceutical interest such as anti-convulsant and sedative drugs ${ }^{[53]}$. Others attributed the neuroprotective potential of anise oil to be through induction of neuronal excitability by activating the $\mathrm{Ca} 2+$ canals or inhibiting the $\mathrm{Ca} 2+/ \mathrm{K}+$ voltage dependent canal $^{[54]}$.

\section{CONCLUSION}

Based on our histological and immunohistochemical results, we can conclud that chronic administration of metanil yellow adversely altered the structure of cerebellar cortex of adult albino rats. So, it is necessary to increase the consumer awareness regarding the serious effects of chronic use of metanil yellow in diet, and to replace it with natural products. In addition, the concomitant administration of anise oil can minimize the hazardous effects of metanil yellow.

\section{CONFLICT OF INTEREST}

There are no conflicts of interest.

\section{REFERENCES}

1. - McKone, H. T. The Unadulterated History of Food Dyes. ChemMatters.1999; pp. 6-7.

2. Attokaran M. Food Colors in: textbook of Natural Food Flavors and Colorants. 2017. DOI: 10.1002/9781119114796.ch5 (C) 2017 John Wiley and Sons Ltd.

3. Dixit S, Purshottam SK, Khanna SK and Das M. Usage pattern of synthetic food colours in different states if India and exposure assessment through commodities preferentially consumed by children. Food Additives and Contaminants. Part
A, Chemistry, Analysis, Control, Exposure and Risk Assessment 2011; 28 (8): 996- 1005.

4. Hashem MM, Atta AH, Arbid MS, Nada SA and Asaad GF. Immunological studies on amaranth sun-set yellow and curcumin as food coloring agents in albino rats. Food and Chemical Toxicology 2010; 48(6): 1581-1586.

5. Seth PK, Jaffery FN, and Khanna VK. "Toxicology," Indian Journal of Pharmacology 2000; 32(4): 134-151.

6. Mathur $\mathrm{N}$ and Bhatnagar P. Mutagenecity assessment of textile dyes from Sanganer (Rajasthan). J. Environ. Biol. 2007; 28: 123-126.

7. Gupta S, Sundarrajan M, Rao KVK. Tumor promotion by metanil yellow and malachite green during rat hepatocarcinogenesis is associated with dysregulated expression of cell cycle regulatory proteins. Teratogenesis Carcinogenesis and Mutagenesis. 2003; (supplement 1):301-312.

8. Nath PP, Sarkar K, Tarafder P, Mondal M, Das K and Paul G. Practice of using metanil yellow as food colour to process food in unorganized sector of West Bengal - A case study International Food Research Journal 2015; 22(4): 1424-1428.

9. Dees C, Askari M, Garrett S, Gehrs K, Henley D and Ardies CM. Estrogenic and DNA-damaging activity of Red No.3 in human breast cancer cells. Environmental Health Perspectives 1997; 105 (3): 625-632.

10. Hausen BM. A case of allergic contact dermatitis due to metanil yellow. Contact Dermatitis 1994; 31(2):117-8.

11. Gupta S, Sundarrajan M and Rao KVK. Annual Conference of the Environmental Mutagen Society of India, symposium on environmental genomics and health sciences, 2002. Lucknow, India.

12. Sarkar R and Ghosh AR. Toxicological effect of Metanil Yellow on the testis of albino rat. International Journal of Basic and Applied Medical Sciences 2012a; 2(2): 40-42.

13. Sarkar R and Ghosh AR. Metanil Yellow - an azo dye induced histopathological and ultrastructural changes in albino rat (Rattus norvegicus). The Bioscan 2012b; 7(3): 427-432.

14. Nagaraja TN and Desiraju T. Effects of chronic consumption of metanil yellow by developing and adult rats on brain regional levels of noradrenaline, 
dopamine and serotonin, on acetylcholine esterase activity and on operant conditioning. Food Chem Toxicol. 1993; 31(1):41-4.

15. Dalal A and Poddar MK. Short-term erythrosine B-induced inhibition of the brain regional serotonergic activity suppresses motor activity (exploratory behavior) of young adult mammals. Pharmacology Biochemistry and Behavior 2009; 92(4): 574-582.

16. Al-Beitawi NA, El-Ghousein SS, Abdullah HN. Antibiotic growth promoters and anise seeds in broiler diets. Jordan Journal of Agricultural Sciences 2009; 5(4):472-481.

17. Iyer SR, Ullagaddi RC, Bondada A. Antihemolytic and anti-inflammatory activities of aniseed (Pimpinella anisum L.). Journal of Advance Pharmaceutical Research and Bioscience 2013; 1(2):52-59.

18. Mata AT, Proenc C, Ferreira AR, Serralheiro MLM, Nogueira JMF, Araujo MEM. Antioxidant and anti acetylcholine esterase activities of five plants used as Portuguese food spices. Food Chem 2007; 103:778-86.

19. Soliman KM, Badea RI. Effect of oil extracted from some medicinal plants on different mycotoxigenic fungi. Food and Chemical Toxicology 2002; 40:1669-1675.

20. Rajeshwari U, Shobha I, Andallu B. Comparison of aniseeds and coriander seeds for antidiabetic, hypolipidemic and antioxidant activities. Spatula DD - Peer Reviewed Journal on Complementary Medicine and Drug Discovery 2011; 1(1):9-16.

21. Kadan S, Rayan M, Rayan A. Anticancer activity of anise (Pimpinella anisumL.) seed extract. The Open Nutraceuticals Journal 2013; 6:1-5.

22. Frankic T, Voljc M, Salobir J, Rezar V. Use of herbs and spices and their extracts in animal nutrition. Acta Argiculturae Slovenica 2009; 94(2):95-102.

23. Yazdi FF, Ghalamkari G, Toghiani M, Modaresi M, Landy N. Anise seed (Pimpinella anisum L.) as an alternative to antibiotic growth promoters on performance, carcass traits and immune responses in broiler chicks. Asian Pacific Journal of Tropical Disease 2014; 4(6):447-451.

24. Karimzadeh F, Hosseini M, Mangeng D, Alavi H, Hassanzadeh GR, Bayat M, Jafarian M, Kazemi H, and Gorji A. Anticonvulsant and neuroprotective effects of Pimpinella anisum in rat brain. BMC
Complement Altern Med. 2012; 12: 76.

25. Abdul-Hamid M and Gallaly SR. Ameliorative effect of Pimpinella anisum oil on immunohistochemical and ultrastuctural changes of cerebellum of albino rats induced by aspartame Ultrastruct Pathol. 2014; 38 (3):224-36.

26. Al-Malki AL, Sayed AA. Bees' honey attenuation of metanil-yellow-induced hepatotoxicity in rats. Evid Based Complement Alternat Med. 2013; 614580.

27. Ramachandani S, Das M, Joshi A, and Khanna SK. Effect of oral and parental administration of metanil yellow on some hepatic and intestinal biochemical parameters," Journal of Applied Toxicology 1997; (17): 85-91.

28. Gaertner DJ, Hallman TM, Hankenson FC, Batchelder MA. Anesthesia and Analgesia for Laboratory rodents In: Fish RE, Danneman PJ, Brown m, Karas AZ editors Anesthesia and Analgesia in Laboratory Animals, 2nd edition. London (UK) Academic Press, 2008; pp 239-297.

29. Bancroft JD, Layton C. 2012. The Hematoxylins and Eosin, Ch:10 and Connective and mesenchymal tissues with their stains, Ch: 11 . In: Suvarna SK, Layton C, Bancroft JD, editors. Theory and Practice of histological techniques, 7th edition, Churchil Livingstone, London, p 173-214. ISBN-13: 9780702042263.

30. Buchwalow I.B. and Böcker W. Immunohistochemistry: Basics and Methods. Springer Heidelberg, Dordecht, London, New York 2010; pp 31-39.

31. Dawson-Saunders B. and Trapp R. Basic and clinical biostatistics, third edition, Lange Medical Book/ McGraw-Hill, Medical Publishing Division 2001; pp 161-218.

32. Saleem N, Umar ZN, Khan SI. Survey on the use of synthetic food colors in food samples procured from different educational institues of karachi city. The journal of tropical life science. 2013; 3(1): $1-7$.

33. Sarkar R. Histopathological changes in the brain of metanil yellow treated albino rat (Rattus norvegicus). International Journal of Basic and Applied Medical Sciences 2013; 3 (2): 256-258.

34. Fritsch P, Richard-Le Naour H, Denis S, Menetrier F. Kinetics of radiation induced apoptosis in the cerebellum of 14-day-old rats after acute or 
during continuous exposure. Int J Radiat Biol 1994; 66:111-117.

35. Ratan RR, Murphy TH and Baraban JM. Oxidative stress induces apoptosis in embryonic cortical neurons. J.Neurochem. 1994; 62(1):376-379.

36. Sobaniec Lotowska ME. Ultrastructure of Purkinje cell perikarya and their dendritic processes in the rat cerebellar cortex in experimental encephalopathy induced by chronic application of valproate. Int.J.Exp.Pathol. 2001; 82(6):337-348.

37. Venkataraman P, Selvakumar K, Krishnamoorthy G, Muthusami S, Rameshkumar R, Prakash S, Arunakaran J. Effect of melatonin on PCB (Aroclor 1254) induced neuronal damage and changes in $\mathrm{Cu} / \mathrm{Zn}$ superoxide dismutase and glutathione peroxidase- 4 mRNA expression in cerebral cortex, cerebellum and hippocampus of adult rats. Neurosci Res 2010; 66:189-197.

38. Li J and Yuan J. Caspases in apoptosis and beyond. Oncogene Rev 2008; 27: 6194-6206.

39. Kitazumi I and Tsukahara M. Regulation of DNA fragmentation: the role of caspases and phosphorylation. FEBS Journal 2010; 278: (2011): 427-441.

40. Abou-Elghait AT, El-Gamal DA, Abdel-Sameea AR, Mohamed AA. Effect of cisplatin on the cerebellar cortex and spinal cord of adult male albino rat and the possible role of vitamin E: Light and electron microscopic study. Egypt J Histol, 2010; 33 (2): 202 - 212.

41. Celik, I., Yilmaz, Z. and Turkoglu, V. Hematotoxic and hepatotoxic effects of dichlorvos at sublethal dosages in rats. Environ Toxicol. 2009; 24(2), 128-132.

42. Kalender, S., Uzun, F.G., Durak, D., Demir, F. and Kalender, Y. Malathion-induce hepatotoxicity in rats: the effects of vitamin $\mathrm{C}$ and $\mathrm{E}$. Food Chem Toxicol.2010; 48: 633-638.

43. Bondy S. C. Free-radical-mediated toxic injury to the nervous system, in: K. B. Wallace (Ed.), Free Radical Toxicology, Taylor and Francis, Oxford. 1997; $221-248$.

44. Verma RS. and Srivastava N. Chlorpyrifos induced alterations in levels of thiobarbituric acid reactive substances and glutathione in rat brain. Ind J Exp Biol, 2001; 39: 174 - 177.
45. Der Perng, M., M. Su, S.F. Wen, T. Gibbon, A.R. Prescott, M. Brenner and R.A. Quinlan, The Alexander disease-causing glial fibrillary acidic protein mutant, R416W, accumulates into Rosenthal fibers by a pathway that involves filament aggregation and the association of alpha B-crystallin and HSP27. Am. J. Hum. Genet. 2006; 79(2): 197-213.

46. Li, D.R., T. Ishikawa, D. Zhao, T. Michiue, L. Quan, B.L. Zhu and H. Maeda. Histopathological changes of the hippocampus neurons in brain injury. Histol. Histopathol., 2009; 24(9): 1113-1120

47. Callaghan JPO and Sriram K. Glial fibrillary acidic protein and related glial proteins as biomarkers of neurotoxicity. 2005; 4(3):433-42.

48. Borlongan CV, Yamamoto M, Takei N, Kumazaki M, Ungsuparkorn C, Hida H, Sanberg PR and Nishino H. Glial cell survival is enhanced during melatonininduced neuroprotection against cerebral ischemia. FASEB J., 2000; 14(10): 1307-1317.

49. Baydas G, Ozer M, Yasar A, Koz ST, Tuzcu M. Melatonin prevents oxidative stress and inhibits reactive gliosis induced by hyperhomocysteinemia in rats. Biochemistry (Mosc) 2006; 71:91-95

50. EL-Hodairy FA. Neuroprotective effects of Pimpinella anisum on neurotoxicity induced by bisphenol A on normal and diabetic rats. International Journal of Pharmacy and Pharmaceutical Sciences. 2014; 6 (3): 9-12.

51. Kahloula K, Slimani M, Adli DEH, Rachdi S, Boumediene D. Neuro beneficial effects of Pimpinella anisum against lead exposure. International Journal of Green Pharmacy $2013 ; 18-24$.

52. Koriem KM, Arbid MS, El-Gendy NF. The Protective Role of Anise Oil in Oxidative Stress and Genotoxicity Produced in Favism. J Diet Suppl. 2016; 13(5):505-21.

53. Waumans D, Bruneel N, Tytgat J. Anise oil as para-methoxyamphetamine (PMA) precursor. Forensic SciInt, 2003; 133(1-2):159-170.

54. Janahmadia M, Farajnia S, VatanparastJ, et al. The fruit essential oil of Pimpinella anisum. (Umblliferae) induces neuronal hyperexcitability in snail partly through attenuation of afterhyperpolarization. Journal of Ethnopharmacology 2000; 120: 360-365. 


$$
\text { الملخص العربى }
$$

\section{التأثير طويل الأمد للميتانيل الأصفر على تركيب قشرة المخيخ لأكورالجرذان البيضاء البالغة والدور}

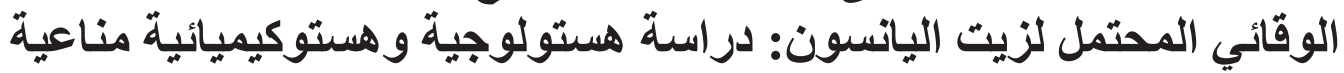

\section{ولاع محمد علوان}

\section{قسم الهستولوجى، كلية الطب ، جامعة طنطا ، طنطا ، مصر}

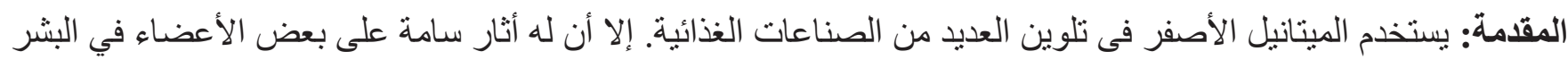

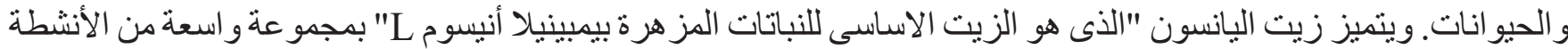

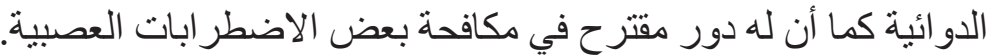
الهـف من البحث: : يهدف هذا العمل إلى دراسة التأثثير طويل الأمد للميتانيل الأصفر على تركيب قثرة المخيخ لذكور الفئران

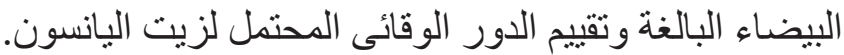

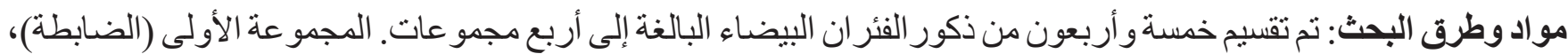

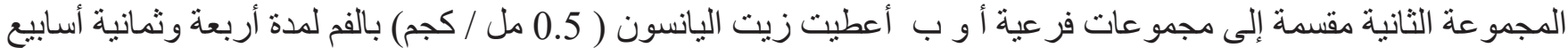

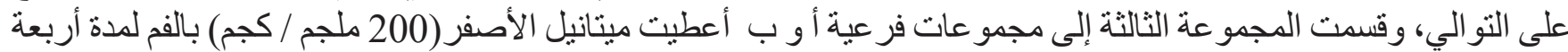

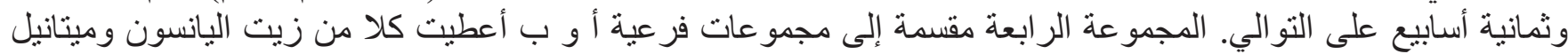

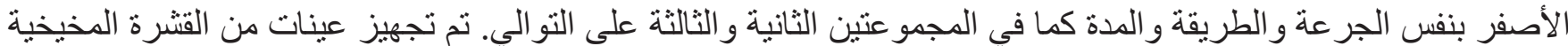
للمجهر الضوئي. كما أجريت در اسة مناعية باستخدام أجسام مضادة لكسبيز 3- وللبروتين الليفى الحمضى للخئ الخلية الدبقية. النتائج : أظهرت عينات من الحيوانات التى أعطيت ميتانيل الأصفر انخفاضا ذو دلالة احصائية عالية في متوسط عدد خلايا

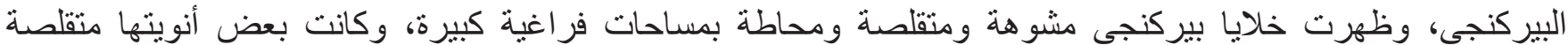

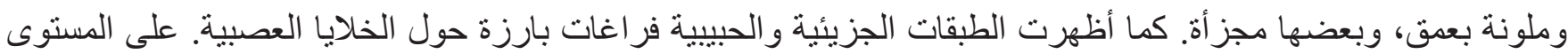
الهستوكيميائي المناعى، فقد لوحظت زيادة ذات دلالة احصائية عالية في نشاط كاسبيز 3- و البروتين الليفى الحمضى للخئية الخلية

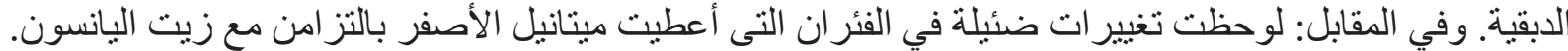

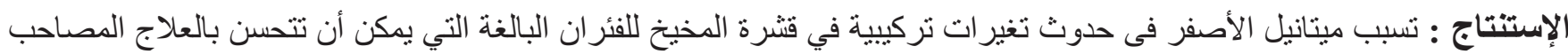
بزيت اليانسون. 